\title{
The Effect of Flossing on Dental Caries: A Critique of Current Literature
}

\author{
Abdulrahman Balhaddad ${ }^{1,2 *}$ \\ ${ }^{1}$ Restorative Dental Sciences Department, University of Dammam, Saudi Arabia \\ ${ }^{2}$ Department of Microbial Pathogenesis, University of Maryland, USA
}

Submission: August 14, 2017; Published: September 14, 2017

*Corresponding author: Abdulrahman Balhaddad, Restorative Dental Sciences Department, University of Dammam, Saudi Arabia and Department of Microbial Pathogenesis, School of Dentistry, University of Maryland, Baltimore, 111 Versailles Cir, Towson, MD, 21204, USA, Tel: 13177374315; Email: aabalhaddad@hotmail.com

\section{Mini Review}

Dental caries is a multi factorial disease due to minerals imbalance in the tooth structure. One of the main etiological factors causing dental caries is dental plaque [1]. Occlusal and proximal surfaces of the tooth structure are more susceptible to plaque accumulation [2]. Within the dental plaque, sufficient amount of cariogenic bacteria could utilize the available carbohydrates inside the oral cavity in order to produce lactic acid and demineralize the tooth structure [3]. Evidence showed that caries prevalence in young individuals is more related to the occlusal surfaces. As for adults, this prevalence is higher in proximal surfaces $[4,5]$. Interproximal plaque was found to be more acidogenic than other surfaces [6]. The routine tooth brushing cleans off the dental plaque from accessible tooth surfaces [7]. However, toothbrushes are not designed to clean the interproximal areas between teeth. Due to toothbrush limitations, dental floss was introduced as an inter dental cleaning tool in 1819 [8]. The dental floss is developed to go between the teeth and get the interproximal plaque off. Eventually, with the correct habitual flossing process, this should eliminate, or reduce the amount of proximal caries [9].

Most of the clinical evidence has indicated that dental floss is not effective to reduce dental caries. Hujoel et al. [10] conducted a systematic-review to investigate the effect of dental floss on proximal caries reduction. Six studies were included in the review. Despite the fact that this systematic review concluded no significant relation between the use of dental floss and dental caries reduction, several points should be emphasized in defense of dental floss. According to Hujoel et al. [10], moderate to high risk of bias was associated with these studies as there was lack of information about the follow-up, randomization method and statistical analyses. In addition, flossing technique was found to have a great impact on the results of these studies. In two studies $[11,12]$, significant proximal caries reduction was observed with professional flossing, where oral health providers performed flossing on school children. Flossing technique in the other four studies was performed either by patients (self-performed) $[13,14]$ or using professional flossing every three months $[15,16]$. This is an important statement, since some studies documented lack of compliance and poor flossing from their patients, which means that the evaluation of the dental floss effectiveness was unfair. Infrequent flossing was not effective to reduce dental caries; this obviously could be concluded from the two studies where professional flossing was performed every three months. It was suggested that fluoride effect might overwhelm the effect of flossing. This was concluded from the fact that professional flossing with low fluoride exposure reduced caries risk by $40 \%$. While in the other four studies [13-16], where there was some kind of fluoride exposure, the flossing effectiveness was negative. The effectiveness of professional flossing could be underestimated as no flossing was performed on summer break and weekends $[11,12]$. Moreover, one of the limitations of these studies is that confounders as fluoride, salivary flow rate, diet, or oral hygiene tools were not controlled, which could affect the results of the experiments. It could be said that when the dental floss is used skillfully and frequently, caries reduction was observed.

Another systematic review by Sambunjak et al. [9] investigated the effect of flossing on dental plaque reduction. Weak evidence was found supporting the use of dental floss and toothbrush, compared to toothbrush only, in order to reduce the dental plaque at 1-3 months. And at six months, No significant difference was found. In this review, twelve studies were included with unclear or high risk of bias. It is important to realize that interproximal surfaces usually are covered by the adjacent teeth. The studies in the review used plaque score indices to assess the plaque accumulation in the visualized surfaces of the proximal tooth structure, but not the un-visualized ones. Therefore, the un-visualized surface, which should be examined, was not assessed in the first place. Usually, dental practitioners diagnose 
dental caries by visual and radiographic examination [17]. In more ideal situation, dental caries could be diagnosed earlier when tooth separation is performed [18], which is practically difficult. It can be seen clearly that the appropriate way to diagnose dental caries in these studies was not used. Also, the absence of actual measures of flossing skill is a major issue in the current evidence; lack of skills and compliance could affect the results of the studies. Vernon and Seacat developed strategies for flossing that might help to establish higher quality flossing evidence [19]. These strategies might assure that subjects in such experiment are able to perform flossing at the same level of skills.

In summary, the studies that investigated the effectiveness of dental floss are unreliable and have moderate to high risk of bias. The fact that there is no strong evidence supports the use of dental floss does not mean that flossing is not effective. On the other hand, flossing was found to be effective reducing periodontal diseases [9]. With no reported complications associated with flossing, oral health practitioners should continue encouraging their patients to floss their teeth. Welldesigned studies are needed in the future to fill the gaps that were found in the literature.

\section{References}

1. Featherstone JD (2003) The caries balance: contributing factors and early detection. J Calif Dent Assoc 31(2): 129-133.

2. Abogazalah N, Ando M (2017) Alternative methods to visual and radiographic examinations for approximal caries detection. J Oral Sci doi: 10.2334/josnusd.16-0595.

3. Marsh PD (2006) Dental plaque as a biofilm and a microbial community-implications for health and disease. BMC Oral Health (6 Suppl 1): S14.

4. Martignon S, Chavarria N, Ekstrand KR (2010) Caries status and proximal lesion behaviour during a 6-year period in young adult Danes: an epidemiological investigation. Clin Oral Investig 14(4): 383390.

5. Mejare I, Stenlund H, Zelezny-Holmlund C (2004) Caries incidence and lesion progression from adolescence to young adulthood: a prospective 15-year cohort study in Sweden. Caries Res 38(2): 130-141.

6. Igarashi K, Lee IK, Schachtele CF (1989) Comparison of in vivo human dental plaque $\mathrm{pH}$ changes within artificial fissures and at interproximal sites. Caries Res 23(6): 417-422.
7. Asadoorian J, Locker D (2006) The impact of quality assurance programming: a comparison of two canadian dental hygienist programs. J Dent Educ 70(9): 965-971.

8. Parmly LS (1819) A practical guide to the management of the teeth: comprising a discovery of the origin of caries, or decay of the teeth with its prevention and cure. In: Parmly LS (ed.), Parmly on the teeth. Philadelphia: Collins \& Croft, ([Philadelphia]: J.R.A. Skerrett), Pennsylvania Philadelphia, United States, p. 198.

9. Sambunjak D, Nickerson JW, Poklepovic T, Johnson TM, Imai P, et al. (2011) Flossing for the management of periodontal diseases and dental caries in adults. Cochrane Database Syst Rev (12): CD008829.

10. Hujoel PP, Cunha-Cruz J, Banting DW, Loesche WJ (2006) Dental flossing and interproximal caries: a systematic review. J Dent Res 85(4): 298-305.

11. Wright GZ, Banting DW, Feasby WH (1979) The Dorchester dental flossing study: final report. Clin Prev Dent 1(3): 23-26.

12. Wright GZ, Feasby WH, Banting DW (1980) The effectiveness of interdental flossing with and without a fluoride dentifrice. Pediatr Dent 2(2): 105-109.

13. Gisselsson H, Bjorn AL, Birkhed D (1983) Immediate and prolonged effect of individual preventive measures in caries and gingivitis susceptible children. Swed Dent J 7(1): 13-21.

14. Granath LE, Martinsson T, Matsson L, Nilsson G, Schröuder U, et al. (1979) Intraindividual effect of daily supervised flossing on caries in schoolchildren. Community Dent Oral Epidemiol 7(3): 147-150.

15. Gisselsson H, Birkhed D, Bjorn AL (1988) Effect of professional flossing with chlorhexidine gel on approximal caries in 12- to 15-year-old schoolchildren. Caries Res 22(3): 187-192.

16. Gisselsson H, Birkhed D, Bjorn AL (1994) Effect of a 3-year professional flossing program with chlorhexidine gel on approximal caries and cost of treatment in preschool children. Caries Res 28(5): 394-399.

17. Gimenez T, Piovesan C, Braga MM, Raggio DP, Deery C, et al. (2015) Visual Inspection for Caries Detection: A Systematic Review and Metaanalysis. J Dent Res 94(7): 895-904.

18. Hintze H, Wenzel A, Danielsen B, Nyvad B (1998) Reliability of visual examination, fibre-optic transillumination, and bite-wing radiography, and reproducibility of direct visual examination following tooth separation for the identification of cavitated carious lesions in contacting approximal surfaces. Caries Res 32(3): 204-209.

19. Vernon LT, Seacat JD (2017) In defense of flossing: can we agree it's premature to claim flossing is ineffective to prevent dental caries? J Evid Based Dent Pract1 7(2): 71-75.

\section{Your next submission with Juniper Publishers will reach you the below assets}

- Quality Editorial service

- Swift Peer Review

- Reprints availability

- E-prints Service

- Manuscript Podcast for convenient understanding

- Global attainment for your research

- Manuscript accessibility in different formats

( Pdf, E-pub, Full Text, Audio)

- Unceasing customer service

Track the below URL for one-step submission https://juniperpublishers.com/online-submission.php 